\title{
THE GREEK INFINITIVE IN VARIABLE DELIBERATIVE, PRINCIPALLY DEPENDENT QUESTIONS: AN INTERPRETATION IN TERMS OF NATURALNESS THEORY
}

In the present paper I investigate the use of the infinitive in dependent deliberative clauses in Greek, a phenomenon occurring in several (modern) languages, cf. Slovene Nisem vedel, kaj storiti. 'I didn't know what to do.', English I didn't know what to do., German Was tun? 'What to do?'1. In the first part I present the development of deliberative infinitive clauses in Post-Classical Greek with a special emphasis on the use of this form in two Early Byzantine prose writings (in Pratum Spirituale and in Vita Theodori Syceotae, both belonging to the $6^{\text {th }} / 7^{\text {th }}$ century $A D$ ), where some peculiarities are observed. In the second part an attempt is made to interpret the basic characteristics of the Greek infinitive in dependent deliberative clauses from the perspective of Naturalness Theory.

The infinitive in the function of dependent deliberative clauses was absent from Classical Greek, cf. below on Kühner-Gerth (1904), II, 23. It has been observed, however, that in Post-Classical Greek as well as in Early Byzantine Greek, the infinitive can be used in such clauses as a substitute for the deliberative subjunctive, cf.

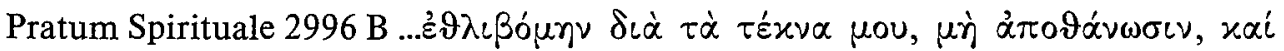
$\tau i$ $\pi \circ \tilde{\eta} \sigma \alpha \iota$ oủx $\eta^{\prime} \delta \varepsilon \iota \nu$. 'I worried that my children would die and I didn't know what to do'.

Jannaris $\left(1969^{2}\right)$, app. VI, $\S 17 \mathrm{c}$, understands the use of the infinitive in dependent deliberative clauses as a sign of the infinitive disappearing from the spoken language and interprets it as incorrect use of the infinitive, since its proper syntactic functions were no longer clear to some of Greek-speaking authors. Apart from Jannaris, the infinitive in dependent deliberative clauses in Greek is referred to in the following sources:

- in Mayser (1929), II, 3, 54, who quotes a case from Ptolemaic papyri, from the $3^{\text {rd }}$ century BC. However, in II, 1, 235, he claims that the case is dubious and that an indefinite pronoun is "freilich denkbar" instead of an interrogative one. He doesn't comment on Jannaris' explanation of the phenomenon, while apparently admitting its occurrence in Post-Classical Greek, cf. loc. cit: "Statt des Konjunk-

1 cf. BDR, $\S 368,6$, Radermacher, op. cit., 181. Unfortunately I do not possess more specific data. The recent investigation into the use of the infinitive in modern European languages (Mayerthaler I, II) does not investigate this syntactic function of the infinitive. 
tivs in abhängigen dubitativen Fragesätzen hat das spätere Griechisch nicht selten den Infinitiv."

- in Kühner-Gerth (1904), II, 23, who rejects the possibility that the infinitive could be used in dependent deliberative clauses in Classical Greek, quoting a dubious case from Herodotus $(1,88)$. But he does claim that the infinitive occurred instead of the subjunctive in dependent deliberative clauses in later Greek, quoting a case from Iosephus (Antiquitates Iudaeorum, 1, 15, 45): $\eta^{\xi} \xi i$ ou

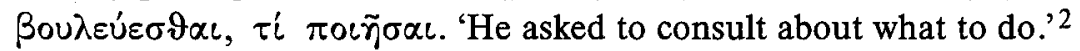

- in Ljungvik (1926), 40, who quotes 3 cases of the infinitive in dependent deliberative clauses.

- in Blass/Debrunner/Rehkopf $\left(1976^{14}\right)$ (BDR), $\$ 368,6$, several such cases from the New Testament are referred to. The infinitive in dependent deliberative clauses in the New Testament is also discussed by Radermacher (1911), 147: "Die Koine hat merkwürdigerweise noch einen Schritt darüber hinaus getan und vereinzelt einen Infinitiv in andersartigen Nebensätzen zugelassen: I Petr. 5,8 ó $\alpha \dot{v} \tau i \delta \iota x \circ \varsigma$

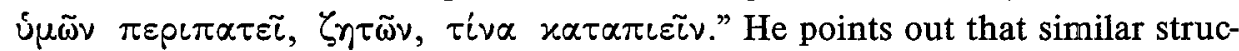
tures occur in German, cf. ibid.: "Auch wir sagen Was tun? Wohin sich wenden?"3

- Hult (1990) in the investigation into the prose syntax of the $5^{\text {th }}$ century AD doesn't mention such clauses from the period, but Mayser (1929), loc. cit., as well as Radermacher (1911), loc. cit., quotes a case from Callinicus, who is characterized by Hult as the most non-literary writer of all the authors she investigated.

It can be argued that Jannaris' explanation of the origin of the construction as quoted above is not the most plausible one for the following reason:

The infinitive is used in the same syntactic function in some modern languages, cf. above. It is therefore not necessary to assume that the infinitive in this syntactic function was a mistake, caused by insufficient knowledge of Greek. Additionally, Jannaris couldn't have been acquainted with the fact that, according to Rohlfs (1977), 191, the infinitive is used in dependent deliberative clauses also in modern South-Italian Greek dialects, e.g. den exo pu pai. 'I don't know where to go'. Rohlfs also states, loc. cit., that the deliberative infinitive can be used in South-Italian Greek dialects in independent clauses, as in Pou pai? 'Where to go?'.

It should be pointed out that South-Italian Greek dialects are believed to be descendants of Ancient Greek Doric dialects. ${ }^{4}$ If this is so, the use of the infinitive

2 "Der Gebrauch des Infinitivs in abhängigen Fragsätzen st. des Konjunktivs gehört erst der späteren Gräzität an." (loc. cit.)

3 The case from the Bible quoted by Radermacher is not reliable. In some editions the interrogative pronoun tivvna is omitted or interpreted an as indefinite pronoun (tina); cf., however, the standard Slovene translation (SSP, Ljubljana 1996): "Vaš nasprotnik hudič hodi okrog kakor rjoveč lev in išče, koga bi požrl."

4 cf. Browning (1969), 130: "It is now clear ... that the speech of these enclaves is the descendant ... of the Greek colonists of Magna Graecia." 
in dependent deliberative clauses in South-Italian Greek dialects cannot be basis for assumptions about Post-Classical spoken Greek, and can be, for the purposes of the present paper, referred to only from a general linguistic viewpoint. The infinitive in dependent deliberative clauses in South-Italian Greek dialects is also discussed by Horrocks (1997), 305, who ascribes it to the influence of Italian. However, he doesn't mention the use of the infinitive in dependent deliberative clauses in PostClassical Greek, cf. loc. cit. ${ }^{5}$ Rohlfs (1962), 113, on the other hand, points out several similarities between the syntax of modern South-Italian Greek dialects and the Greek of the Post-Classical period; he observes that in South-Italian Greek dialects, as well as in Post-Classical Greek, the infinitive is an obligatory complement only to the verb 'can', while after 'want' both infinitive and object clauses occur. ${ }^{6}$ According to Horrocks (1997), loc. cit., these dialects became detached from the mainland Greek at the end of the $11^{\text {th }}$ century, which is why they "preserved a great many archaic features, some of which go back to Koine spoken in ancient Magna Graecia" (loc. cit.). ${ }^{7}$

In cases such as those quoted above, the infinitive in dependent deliberative clauses should obviously be interpreted as a construction parallel to the deliberative subjunctive in dependent interrogative clauses (cf. Kühner-Gerth, op. cit., referred to above). In terms of the main semantic opposition between the dynamic and declarative infinitive, ${ }^{8}$ referred to in the majority of modern studies that investigate the syntax of Greek infinitive clauses, ${ }^{9}$ the infinitive clauses quoted above cannot be interpreted as declarative. Consequently, they pertain to the category of dynamic infinitive clauses, which refer to a non-factual action. ${ }^{10}$

\section{The infinitive in dependent deliberative clauses in the investigated authors}

In the two investigated Early Byzantine authors, the following infinitive clauses can be interpreted as dependent deliberative infinitive clauses:

\footnotetext{
5 What he mentions is the use of deliberative infinitive clauses in medieval Greek literature (in Digenes Akrites) and in Cretan Renaissance literature.

6

South-Italian Greek dialects exhibit traces of other influences apart from the ancient Greek dialects. According to one hypothesis, they were strongly influenced by the inhabitants who settled in South Italy in the Byzantine period, cf. Rohlfs (1962), 115, Joseph (1983), 74, Horrocks (1997), loc. cit.

7 Horrocks (1997), loc. cit.

8 The terms 'dynamic' and 'declarative' infinitive go back to Kurzová (1968); the latter corresponds to an infinitive dependent on the verbs of speaking and thinking (semantically referring to a factual action), while the former refers to an infinitive dependent on the verbs of ordering and modal verbs (referring to a non-factual action).

9 On the use of the two terms in modern literature, cf. Rijksbaron (1984), 101.

10 cf. Jannaris (19682), loc. cit., who discusses infinitive deliberative clauses in the chapter on the prospective infinitive (which corresponds to the term 'dynamic infinitive').
} 


\section{Vita Theodori Syceoatae}

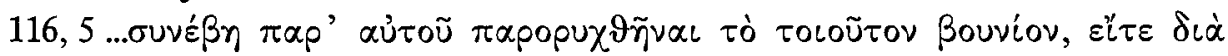

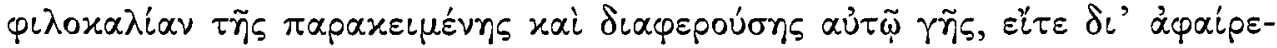

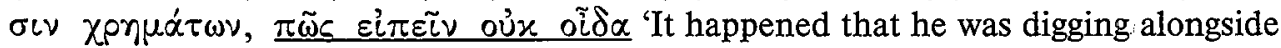
this hill, either in order to adorn the piece of land that lay there and belonged to him, or in order to take away money, I can't tell how (or: I don't know how to explain)'.

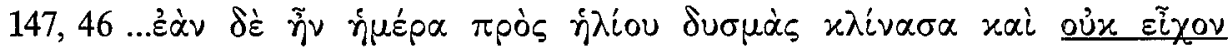

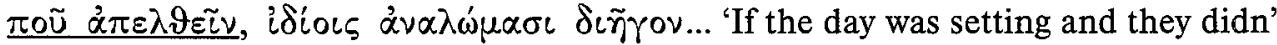
$\mathrm{t}$ know where to go, they spent the night at their own expense'.

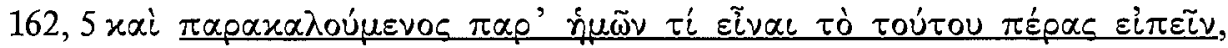


'When he was asked to tell us what was the end of it, he said that he knew but couldn't tell us exactly'.

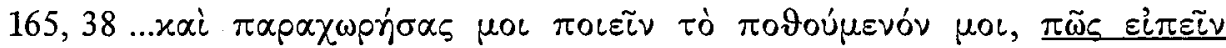

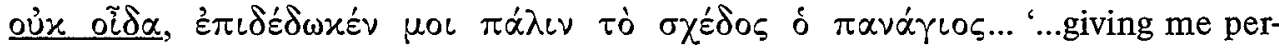
mission to do what I desired, I can't tell how (or: I don't know how to explain), the holy man put the piece of paper back into my hands'.

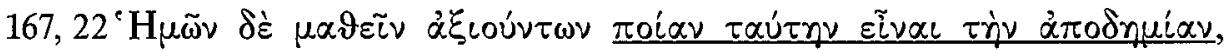
$\alpha i v e \gamma \mu \alpha \tau \omega \delta \tilde{\omega} s \varepsilon \tilde{i} \pi \varepsilon \nu . .$. 'When we asked to learn what this absence meant, he said cryptically...'.

There is some caution necessary, since interrogative pronouns in Greek often differ from the corresponding indefinite pronouns only in respect of the word accent. If an interrogative pronoun is taken as indefinite, the dependent infinitive might be understood as object complement to the governing verb if the latter is transitive. In the case of a phenomenon as rare as deliberative infinitive clauses, the possibility of a scribe's error might be considered, cf. Mayser (1929) II, 3, 54, on $\tau i$ $\pi$ oiñ $\sigma \alpha$. This category of dubious cases may include Vita 147,46 . The manuscript tradition, however, is certain in these cases, which makes the doubt less well-founded. ${ }^{11}$

Concerning clauses 116, 5 and 165, 38, it can be noted that they are not necessari-

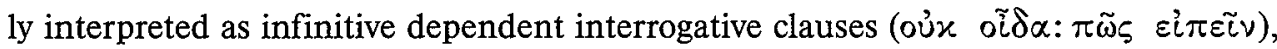
since the infinitive can also be understood as the dynamic infinitive dependent on oi $\delta \alpha$; in this case, the dependent interrogative clause consist only of the interroga-

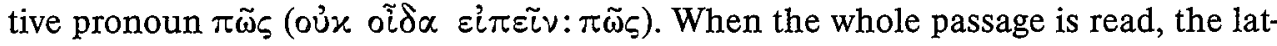
ter interpretation seems slightly more probable, since in both cases the emphasis lies on how the action could have happened (in clause 116, 5, on the fact that the farmer was digging alongside the hill, and in 165,38 , on the fact that Theodor allowed Georgios to write his biography); the writer is probably not asking how to express

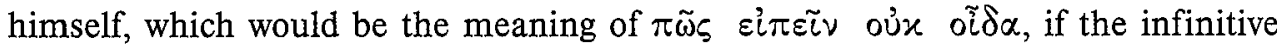
clause is interpreted as dynamic.

11 cf. Rosenquist (1981), $95 \mathrm{f}$ 
Concerning the cases of infinitive dependent interrogative clauses occurring in Vita Theodori Syceotae, a remarkable feature can be observed, namely that in two cases (Vita 162, 5 and 167,22) the infinitive cannot be interpreted as a substitute for the deliberative subjunctive. If a finite verbal form was used in these cases, it would be either the indicative or possibly, in Classical Greek, the optativus obliquus, on which cf. below. Consequently, the two infinitive clauses can hardly be interpreted as dynamic, such as deliberative infinitive clauses (cf. above).

\section{Pratum Spirituale 12}

2996 B see above

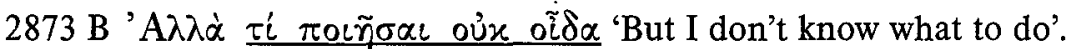

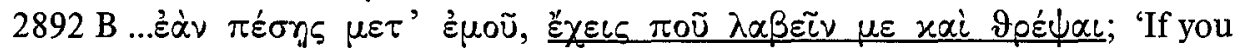
lie down with me, do you know where to take me and feed me?'

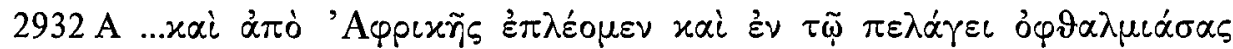

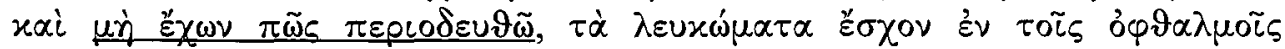
rou... 'We were sailing from Africa, I suffered from ophthalmia at sea and not knowing how to walk around, I had white spots in the eyes...'.

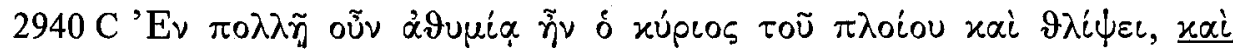

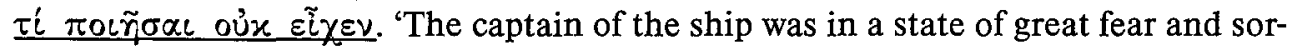
row and he didn't know what to do'.

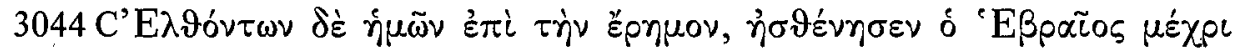

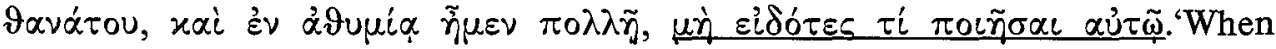
we came to the desert, the Hebrew fell deadly sick, and we were in a state of great fear, not knowing what to do with him'.

In some of the above cases it should be taken into consideration that the pitch accent had disappeared from Greek by the Early Byzantine period. One can therefore ask what phonetic difference, if any, there was between the stressed and the unstressed pronoun ti and, in clause $2892 \mathrm{~B}$, between the circumflex and the grave

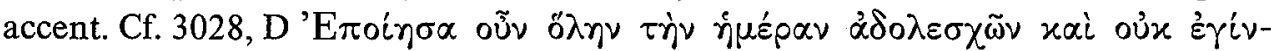

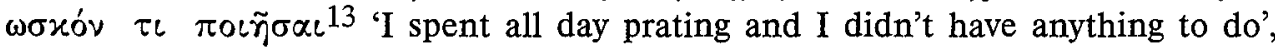
where, if the accent changes, the dependent (non-deliberative) infinitive clause becomes a dependent deliberative clause. However, this observation does not refer

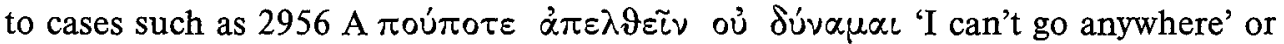

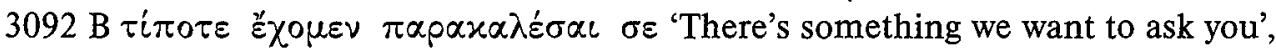
where the pronoun is doubtlessly an indefinite one. In the ambiguous cases, where

12 cf. Mihevc-Gabrovec (1960), 75

13 In Mihevc-Gabrovec (1960), loc. cit., this case is listed among dependent deliberative clauses. But the pronoun in this clause is accented as interrogative and not indefinite when one follows Migne's edition of the

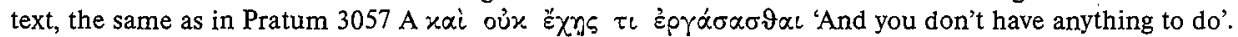


n't know what to do'. 
the difference between the interrogative and indefinite pronoun is one of the word accent, it can be assumed that the phonetic difference in the spoken language lay in the clause intonation, ${ }^{14}$ an assumption that cannot be proved for obvious reasons. In the interpretation below I follow the manuscript tradition and do not consider these cases questionable.

The above cases quoted from Pratum Spirituale and Vita Theodori Syceotae can be divided into two groups:

(1) the infinitive in dependent deliberative clauses, occurring after the governing verb (oủx) है $\chi \omega$ '(not) have' or (oủx) oĩ $\delta \alpha$ '(not) know' (9 cases)

(2) the infinitive in non-deliberative dependent interrogative clauses ( 2 cases)

All of the above dependent infinitive clauses are variable interrogative clauses; polar interrogative clauses do not occur in the form of dependent infinitive clauses, either in the investigated authors or in other consulted sources. In the present paper only variable interrogative clauses are subsumed under the term 'deliberative clauses'.

\section{Group 1}

Historically speaking, these cases can be explained as extended use of the dynamic infinitive, dependent on the verbs है $\chi \omega$ 'have' and oi $\delta \alpha$ 'know'. The verbs that can govern deliberative infinitive clauses can also govern the dynamic infinitive. ${ }^{15}$ This explanation goes back to Jannaris, op. cit., $\S 2093$, who claims, in a statement different from the one quoted at the beginning of the paper, that Post-Classical Greek "conceives ou่x है $\chi \omega, \dot{\alpha} \pi \circ \rho \tilde{\omega}, \sigma x \circ \pi \tilde{\omega}$ and the like as negative terms of $\delta \dot{u} v \alpha \mu \alpha \iota, \dot{\varepsilon} \chi \omega, \varepsilon \dot{\varepsilon}-$ $\pi \circ \rho \tilde{\omega}$ etc., and thus constructs them with the infinitive, not with the subjunctive /.../

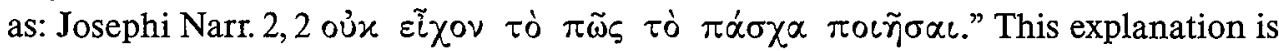
also supported by cases such as Pratum Spirituale 3028 D, on which cf. above.

It can also be argued that the infinitive in dependent deliberative clauses belonged to spoken Greek, not only since the sources containing the infinitive in dependent deliberative clauses generally reflect a level of style close to the conditions in the spoken language, ${ }^{16}$ but also on the basis of the investigated authors. Most of the quoted cases of the infinitive in dependent deliberative clauses are from Pratum Spirituale, a document exhibiting many traces of the developments in the contemporary spoken language. ${ }^{17}$ Moreover, the majority of the cases occur inside passages written in the form of direct speech. The ratio between deliberative infinitive clauses in direct and indirect speech is 6:3. For these reasons (as well as for other

14 Similarly as in modern Greek in the case of the relative and interrogative $\pi$ ou.

15

cf. e.g. LSJ, s.v. oĩ $\delta \alpha$ and $\check{z} \chi \omega$

6 cf. the sources referring to deliberative infinitive clauses quoted at the beginning of the paper. However, in the Chronicle of John Malalas, a prose text contemporary with Pratum Spirituale and Vita Theodori Syceotae, which is also believed to be one of the crucial documents of the spoken language of the time, I find no cases of deliberative infinitive clauses, neither are they quoted in other consulted sources.

17

cf. e.g. Horrocks (1997), 186 
reasons that have already been stated at the beginning of the paper), Jannaris' interpretation quoted at the beginning of the paper is less likely.

This group reveals the following characteristics:

- In all nine cases, there are only two governing verbs introducing the dependent deliberative infinitive clause, namely oĩ $\delta \alpha$ 'know' and है $\chi \omega$ 'have'.

- The subjects of the governing verb and of the dependent deliberative question are co-referential.

Judging from the above quotations, it seems that the infinitive in dependent deliberative clauses occurred only after certain governing verbs. One could also assume that only a limited number of verbs could be used in the dependent deliberative infinitive clause. However, the above quotations are not necessarily taken as statistically significant. Ljungvik (1926), loc. cit., quotes 3 cases, in 2 of which the infinitive occurs after (oủx) है $\chi \omega$ '(not) have'. Jannaris $\left(1968^{2}\right)$ quotes altogether 16 cases of the infinitive in dependent deliberative clauses, 9 of them occurring after

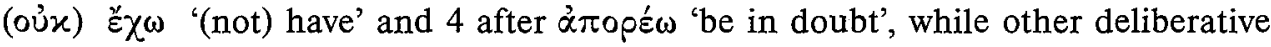
infinitive clauses are construed with other verbs. In the opening clause of the paragraph, he claims that the infinitive in dependent deliberative clauses occurs "after

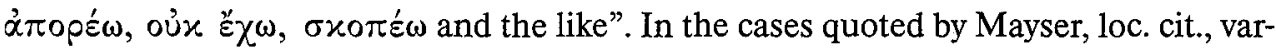
ious verbs are used in the governing clause as well as in the dependent infinitive clause. The use of the infinitive in dependent deliberative clauses was possibly limited to certain governing verbs, but due to the contrary cases this is impossible to claim. It is also uncertain if the verbs that could govern infinitive deliberative clauses occurred any less frequently in the role of the governing verbs of subjunctive deliberative clauses. Mayser (1929) I, 2, 235, quotes several cases of (oủx) है $\chi \omega$ 'not have' governing deliberative subjunctive clauses, cf. also the above quotation from Pratum Spirituale 2932 B. In order to examine the distribution of governing verbs in the infinitive/subjunctive dependent deliberative clauses, a more extensive research would be needed since the investigated authors employ very few dependent deliberative clauses.

As stated above, in all quotations from the investigated authors, the subject of the governing clause and the subject of the infinitive clause are co-referential. Judging from other consulted sources quoted at the beginning of the paper, the same observation applies to dependent deliberative infinitive clauses in other authors as well. In contrast to group 2 (cf. below), there are no cases of AcI ('the accusative with the infinitive') in group 1, either in the investigated authors or in other consulted sources.

The co-reference of subjects is not necessary in dependent deliberative clauses. Cases without co-reference can easily be imagined and are also attested in Greek, cf. Mayser (1929) II, 1, 235, who quotes the following clause from Ptolemaic papyri: " $v \alpha$

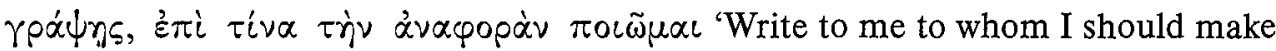
the report'. 


\section{Interpretation in terms of Naturalness Theory}

This chapter attempts to interpret the use of the infinitive in dependent deliberative clauses in Greek from the perspective of Naturalness Theory, as it has developed in its most recent version at the University of Ljubljana under the guidance of Professor Janez Orešnik ('the Slovenian Theory'). The first part briefly presents the basic principles of Naturalness Theory, while the second part interprets the characteristics of deliberative infinitive clauses as presented above.

The basic terms used in Naturalness Theory are 'natural' and 'naturalness'. Naturalness Theory distinguishes 'sem' and 'sym naturalness'. The term 'sem natural' (abbreviated as 'sem') refers to naturalness from the speaker's viewpoint, and the term 'sym natural' (abbreviated as 'sym') from the hearer's viewpoint. Naturalness from the speaker's viewpoint is defined as "naturalness of an expression in terms of its semantic complexity", Orešnik (2001), 11, and naturalness from the hearer's viewpoint as "naturalness of an expression in terms of its coding properties", ibid. The term 'sem natural' can be replaced with the term 'natural' (abbreviated as 'nat'). Naturalness Theory sees two tendencies operating in the language, the interest of the speaker and the interest of the hearer. It assumes that the two tendencies are contrary to one another.

The Slovenian Theory investigates the properties of syntactic variants. At its earliest stages only two morphological or syntactic units which express precisely the same meaning could be understood as variants, e.g. an object clause and an infinitive clause, reported speech and direct speech. Later the term was broadened in the sense that any pair of morphological or syntactic units belonging to the same superordinate grammatical category can be taken as variants, e.g. the definite and indefinite article, cf. Orešnik (2001), 15.

When a pair of syntactic constructions are understood as variants, one of them is more sem natural and the other less sem natural. When $A$ is more sem natural than $B$, this is expressed in the form of a naturalness scale as follows:

$>\operatorname{sem}(\mathrm{A}, \mathrm{B})$ (or >nat $(\mathrm{A}, \mathrm{B}))$

The Slovenian Theory expands the basic scale $>\operatorname{sem}(A, B)$ into two additional scales that refer to optional usage of $A$ or $B$ :

$>\operatorname{sem}(\mathrm{A}+\mathrm{B}, \mathrm{B})$

$>\operatorname{sem}(\mathrm{A}, \mathrm{A}+\mathrm{B})$

According to the former of the two additional scales, admitting both the more and the less sem natural variant is more natural than admitting only the less sem natural variant. According to the latter, admitting only the more sem natural variant is more natural than admitting the more and the less sem natural variant, cf. Orešnik (2004), 12. An expanded scale $(>\operatorname{sem}(A+B, B)$ or $>\operatorname{sem}(A, A+B))$ is true when the corresponding basic scale $(>\operatorname{sem}(A, B))$ is true.

Naturalness Theory assumes that the more sem natural variant tends to be used in more sem natural (less complex) circumstances than the less sem natural variant 
(i. e. that the more sem natural variant associates in at least one respect with a more sem natural parameter than the less sem natural variant). This assumption is expressed in the form of the following alignment rules:

$>$ sem tends to align with $>$ sem

$<$ sem tends to align with <sem

The following passage states the ten criteria used in the Slovenian Theory in determining the naturalness value of syntactic variants, cf. Orešnik (2004), 14/5. They are a fundamental contribution of the Slovenian Theory to Naturalness Theory. I thank Professor Orešnik for kindly allowing me to quote the passage and adapt it to the needs of the present paper.

(A) The criterion of least effort. What conforms better to this principle is more natural. What is cognitively simple (for the speaker) is easy to produce, easy to retrieve from memory, etc.

(B) Phylogenetic age. What is older phylogenetically is more natural. What is cognitively simpler (for the speaker) is acquired earlier by the language.

(C) Prototypicality. What is nearer to the prototype is more natural.

(D) Degree of integration into the clause. What is better integrated into its clause is more natural. This partially exploits (C): the prototypical syntactic situation is for a syntactic element to be well integrated into its syntactic construction.

(E) Frequency. What is more frequent in a language tokenwise is more natural. What is cognitively simpler (for the speaker) is used more. (However; the inverse situation does not obtain: what is natural is not necessarily frequent.)

(F) Small v. large class. The use of a unit pertaining to a small class is more natural than the use of a unit pertaining to a large class. During speech small classes are easier for the speaker to choose from than are large classes.

(G) Specialized v. non-specialized use. If there exists a specialized way of expressing a category, that specialized way is very natural as an expression of the category in question. If, for example, a language has reflexive personal pronouns, they are specialized to express reflexivity (whereas other personal pronouns are not specialized to express reflexivity, even if they may express it under certain circumstances), and their use to express reflexivity is very natural: >sem (+reflexive, -reflexive)/personal pronoun as expression of reflexivity.

(H) Use v. non-use. The use of a category or process is more natural than its nonuse. This generalization is based on the following consideration. All kinds of categories occur in the most natural lexical items, paradigms and constructions of the language, and ebb on the way out of that core. An example is a language whose noun phrases distinguish the singular, plural and dual. Although the singular, plural and dual are not equally natural with respect to one another, each of them is highly natural in its own field. For instance, the dual is highly natural as an expression of duality: >sem $(+,-) /$ dual in expressions of duality. This correlates with the circumstance that the dual (in fact all three numbers) is 
present in personal pronouns, i.e. in the most natural noun phrases, while it may be present to different degrees in the remaining noun phrases of the language.

(I) Acceptable v. non-acceptable use. What is acceptable is more natural than what is not acceptable. The very reason for the acceptability of a syntactic unit is its greater naturalness with respect to any corresponding non-acceptable unit.

(J) What is more widespread in the languages of the world is more natural (the typological criterion). What is cognitively simpler (for the speaker) is realized in more languages.

\section{Infinitive deliberative clauses from the perspective of Naturalness Theory}

In terms of Naturalness Theory, infinitive dependent deliberative clauses represent a syntactic variant of subjunctive dependent deliberative clauses. The investigated texts themselves contain several cases of the subjunctive used in dependent

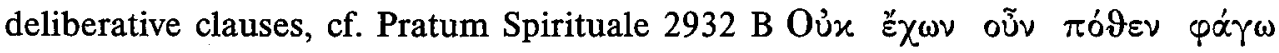
$\lambda \circ \iota \pi$ ò , ह้ $x \lambda \varepsilon \pi \tau \circ \nu$ 'So, not knowing what to eat, I was stealing'.

From the perspective of Naturalness Theory, an infinitive dependent deliberative clause is the more sem natural variant and a subjunctive dependent deliberative clause the less sem natural variant:

>sem (infinitive, subjunctive)/dependent deliberative clauses

Since in this case the opposition between the two syntactic variants (infinitive dependent deliberative clause, subjunctive dependent deliberative clause) is the opposition between an infinitive (non-finite) dependent clause and a finite dependent clause, the criteria for determining the naturalness value of the two syntactic variants are basically the same as could be applied to any pair of variants containing an infinitive (non-finite) dependent clause and a finite dependent clause:

- criterion (D) of integration into the clause: Greek presents a clear example of how infinitive clauses are more integrated into the clause structure than finite dependent clauses. In Classical Greek the negative particle oủx 'not' can be raised from dependent infinitive clauses (cf. clauses of the type Oủx है $\varphi \eta$ हiं $\delta$ ' vac 'He said he didn't know'), ${ }^{18}$ a feature absent from the syntax of finite dependent clauses. Moreover, infinitive clauses use reflexive pronouns to refer to the subject of the governing verb (as do independent clauses), which is not the case with finite object clauses. ${ }^{19}$

- criterion (A) of least effort: ${ }^{20}$ one can argue that infinitive clauses generally demand less effort from the speaker's viewpoint, since one word at most is nec-

\footnotetext{
18 cf. Babič (1997)-1, 110

19 This observation refers to the Greek of the investigated period, while in Classical Greek reflexive pronouns referring to the subject of the governing verb, could also be used in finite object clauses, cf. Babic (1997)-1, 77 .

20

cf. Orešnik (2004), 14
} 
essary to form an infinitive clause (i.e. the infinitive), while at most two words are necessary in the case of finite object clauses (i.e. a finite verbal form and a conjunction); cf. Mayerthaler I, 153: "Infinitivbildungen dienen vor allem der Kodierungsökonomie. Sie führen zur Reduktion der Anzahl lexikalisierter Elemente in der Satzkonstruktion."

- criterion (B) of phylogenetic age: it can be observed that in Greek infinitive clauses (dependent on the verbs of speaking) are attested already on the Mycenian tablets. $^{21}$ Finite object clauses, on the other hand, are not. ${ }^{22}$ Although the Mycenian tablets are not an absolute proof that infinitive clauses developed at an earlier stage in Greek than finite dependent clauses, they suggest at least a very early development of infinitive clauses.

In the present paper, the following characteristics of infinitive dependent deliberative clauses in Greek are interpreted from the perspective of Naturalness Theory:

- The infinitive is used in dependent deliberative clauses only in the case of co-referential subjects.

- The Greek of the investigated period reveals only dependent infinitive deliberative clauses, while independent ones are not attested.

- Historically speaking, the infinitive in deliberative clauses occurred later in the history of Greek than the infinitive in non-deliberative clauses. In order to interpret this fact from the perspective of Naturalness Theory (which is primarily a synchronic theory), a period has to be assumed in the history of Greek when the infinitive was absent from deliberative clauses and could only be used in nondeliberative clauses. ${ }^{23}$

The subject-matter will be treated in 'deductions' I - III. Each deduction indicates the presuppositions which must obtain for the state of affairs considered to be predictable.

\section{Deduction I:}

I. Variants: infinitive dependent deliberative clauses, subjunctive dependent deliberative clauses

\section{Naturalness scales:}

1.1. >sem (infinitive, subjunctive)/dependent deliberative clauses

- cf. above

1. 2. $>$ sem $(+,-) /$ co-referential subjects

21 cf. Babič (1997)-2, 120

22 Due to the nature of the texts, the latter could be coincidental. However, infinitive clauses in Greek obviously go back to the earliest stages of the language.

23 It has been referred to above that possibly only a certain group of verbs governed deliberative infinitive clauses. This feature, when proved, could easily be interpreted in terms of Naturalness Theory according to the criterion $(F)$ of small class. 
- according to the criterion (A) of least effort; in the case of co-reference, the subject is repeated, which is easier for the speaker than to provide a new piece of information 1.2.1 >sem $(+, \pm) /$ co-referential subjects

- the scale is of the type $>\operatorname{sem}(A, B) \rightarrow>\operatorname{sem}(A, A+B)$

\section{Alignment rules:}

2.1. $>$ sem tends to align with $>$ sem

2.2. <sem tends to align with <sem

3. Prediction: If there is any difference between infinitive and subjunctive dependent deliberative clauses, such that one type of dependent deliberative clause can be used in the case of both co-referential and non co-referential subjects, and the other type only in the case of co-referential subjects, it is expected that infinitive dependent deliberative clauses can be used in the case of co-referential subjects, while subjunctive dependent deliberative clauses can be used in the case of both co-referential subjects and non co-referential subjects.

Another feature of deliberative infinitive clauses in the investigated authors is that only dependent ones are used, while independent ones do not occur. Judging from South-Italian Greek dialects, this is not the only possible situation, not even in Greek. From the perspective of Naturalness Theory, dependent infinitive clauses are more natural than independent infinitive clauses; Mayerthaler I, 154, suggests the following naturalness scale:

>sem (hypotaktischer, absoluter)/INF

The scale is supported by the criterion (J) of typology.

From the perspective of the Slovenian Theory, the same scale can be supported by the following criteria:

- according to the criterion (B) of phylogenetic age. In Greek, dependent infinitive clauses developed earlier than independent infinitive clauses; Greek infinitive endings go back to dative or locative abstract nouns. ${ }^{24}$ Consequently, at least for the earliest periods of Greek, it cannot be expected that the infinitive could have been used at all in independent clauses.

- according to the criterion (E) of frequency; in Greek, dependent infinitive clauses are used much more frequently than independent ones, even in Classical Greek, cf. Kurzová (1966), 40: "Gebrauch von Infinitivkonstruktionen in der Funktion eines selbständigen Satzes ist im Griechischen nur auf die, im klassischen Griechisch übrigens nur sporadisch belegte, imperativische Verwendung beschränkt."

- according to the criterion (C) of prototypicality, cf. above on the phylogenetic criterion and on the criterion of frequency.

When it is supposed that in the investigated period the infinitive was not used in independent deliberative clauses, the situation is explained in terms of Naturalness Theory as follows:

24 cf. e.g. Schwyzer (1959²), 358 
Deduction II:

Variants: dependent infinitive deliberative clauses, independent infinitive deliberative clauses

\section{Naturalness scales:}

1.1. >sem (+, -)/dependent infinitive deliberative clauses

- according to the criterion (E) of frequency

- according to the criterion (B) of phylogenetic age

- according to the criterion (J) of typology

- according to the criterion (C) of prototypicality

1.2. $>$ sem $(+,-) /$ acceptable

- see above, criterion (I)

\section{Alignment rules:}

2.1. $>$ sem tends to align with $>$ sem

2.2. $<$ sem tends to align with <sem

3. Prediction: If there is any difference between dependent infinitive deliberative clauses and independent infinitive deliberative clauses, such that one of the two types of infinitive clause is acceptable and the other is not acceptable, it is expected that dependent infinitive deliberative clauses are acceptable and independent ones are not acceptable.

As has been mentioned above, the Greek dialects spoken in South Italy reveal the use of independent infinitive deliberative clauses alongside dependent ones. Since no instances of independent infinitive deliberative clauses are attested, either in the investigated authors or in other consulted sources, the situation in South-Italian Greek dialects suggests that the infinitive in independent deliberative clauses developed in Greek at a later stage than the infinitive in dependent deliberative clauses. If it is supposed that independent infinitive deliberative clauses developed from dependent ones, it can be claimed from the perspective of Naturalness Theory that, according to the criterion (B) of phylogenetic age, independent infinitive deliberative clauses are less sem natural than dependent ones.

Deduction III explains the fact that at a certain stage in the development of Greek (i.e. in Classical Greek, cf. the beginning of the paper), only non-deliberative dependent infinitive clauses were used. In other words, deliberative dependent

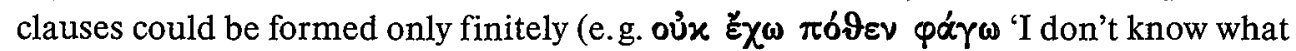

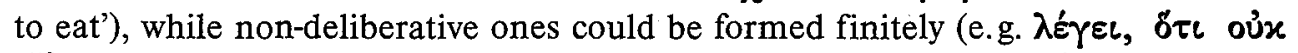

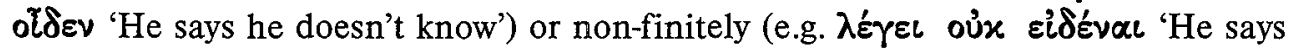
he doesn't know').

Variants: deliberative dependent infinitive clauses, non-deliberative dependent infinitive clauses

\section{Naturalness scales:}

1.1. >sem (-deliberative, +deliberative)/dependent clauses/in Classical Greek 
- according to the criterion (A) of least effort; an additional element, namely an interrogative pronoun, is necessary to form a deliberative clause

1.2. >sem $(-,+) /$ finite dependent clause

- cf. above, p. 58

1.2.1. >sem $( \pm,+)$ /finite dependent clause

- the scale is of the type $>\operatorname{sem}(A, B) \rightarrow>\operatorname{sem}(A+B, B)$

\section{Alignment rules:}

2.1. $>$ sem tends to align with $>$ sem

2.2. <sem tends to align with <sem

3. Prediction: Within dependent clauses of Classical Greek, if there is any difference between non-deliberative and deliberative clauses, such that one type of clause could be formed both finitely and non-finitely and the other type only finitely, it is expected that non-deliberative clauses could be formed both finitely and non-finitely, and deliberative clauses only finitely.

\section{Group 2}

This group comprises only two examples, both from Vita Theodori Syceotae. What divides them from group 1 is that their meaning cannot be interpreted as deliberative. The expected form in an equivalent finite dependent clause would not be the subjunctive but the indicative. Another possibility in Classical Greek or in Post-Classical archaising literature would be the potential optative, cf. Pratum 2929

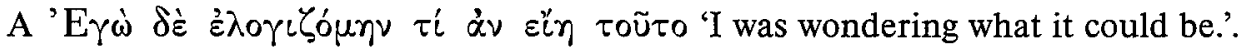

Another difference is that in both cases AcI is used in the dependent interroga-

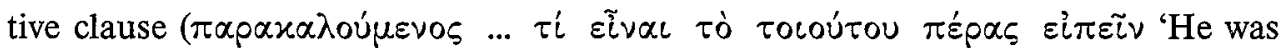

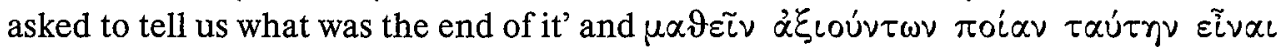
$\tau \dot{\eta} \nu$ ' $\pi \circ \delta \eta \mu i \alpha \nu$ 'When we asked to learn what this absence meant...'). This construction does not occur in group 1, where the subject of the infinitive clause is omitted in all cases.

The third difference between the two groups of interrogative infinitive clauses lies in the form and the meaning of the governing verb, the verbs $\lambda \dot{\varepsilon} \gamma \omega$ 'say' and $\mu \alpha \nu \vartheta \alpha$ ' $v \omega$ 'learn' not being attested as governing verbs in group 1. Moreover, the governing verbs in the two cases of group 2 occur in the infinitive form (the structure

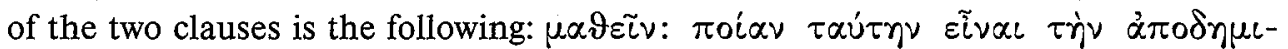

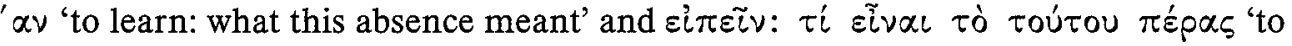
tell: what was the end of it'). Consequently, another interpretation can be suggested, namely that the use of the infinitive in the two dependent (interrogative) clauses was influenced by the form of the governing verb.

In the consulted sources quoted at the beginning of the paper I found no mention of the infinitive used in non-deliberative dependent interrogative clauses, which presents another difficulty for the interpretation of this type of clause. If the meaning of the infinitive in the two dependent interrogative clauses is assumed to be 
potential, a motivation for the use of the infinitive in group 2 could be seen in the retreat of the optative from the spoken language.

Another problem lies in characterizing the stylistic value of these two cases. Neither of them occurs in the passages written in the form of direct speech, which makes it less likely that this was a feature of the spoken language. Since the infinitive was disappearing from the spoken language at the time, the two clauses of group 2 could be interpreted as hypercorrect.

If this interpretation is adopted, it could be questioned whether the two clauses are suitable for the Naturalness Theory approach at all, since Naturalness Theory studies phenomena that develop in a language spontaneously. If, on the other hand, interrogative infinitive clauses of non-deliberative meaning are taken to have been more than a (hypercorrect) feature of the written language, the following can be claimed about them. As regards the semantic distinction between the dynamic and declarative infinitive (cf. above), these clauses could hardly be interpreted as cases of the dynamic infinitive; rather, they pertain to the category of the declarative infinitive. In terms of Naturalness Theory, the latter is less sem natural than the former. The scale >sem (dynamic infinitive, declarative infinitive) is supported according to the criterion $(\mathrm{J})$ of typology. ${ }^{25}$ Consequently, it is consonant with the assumptions of Naturalness Theory that non-deliberative interrogative infinitive clauses developed in the history of Greek at a later stage than deliberative ones. ${ }^{26}$ Another feature of non-deliberative interrogative infinitive clauses, namely that they occur only in the form of AcI, whereas the subject of deliberative infinitive clauses is regularly omitted, can be interpreted from the perspective of Naturalness Theory as follows. Since AcI is a less sem natural variant than an infinitive clause with subject omission (according to the criterion (A) of least effort), it is expected that AcI associates with the less natural form of the infinitive clause, in this case, with the non-deliberative interrogative infinitive clause.

To sum up, even the use of interrogative infinitive clauses with a non-deliberative meaning, a very rare phenomenon that has not yet been fully investigated in Greek, it is congruous with the expectations of Naturalness Theory. However, the latter cannot answer the question about the status of such clauses in the contemporary spoken language.

25 cf. Orešnik (1999), 56f; Mayerthaler II, 213
26 according to the criterion (B) of phylogenetic age 


\section{Bibliography}

BDR: Blass/Debrunner/Rehkopf (1976 $\left.{ }^{14}\right)$ : Grammatik des neutestamentlichen Griechisch, Göttingen

BABIC (1997)-1: Grška slovnica, Ljubljana

BABIC (1997)-2: Besedni red in zgradba besedil na mikenskih tablicah, Ljubljana

BRowNING (1969): Medieval and Modern Greek, London

Hessering (1931): Jean Moschos, Paris

HorRocks (1997): Greek, A History of the Language and its Speakers, London and New York

HULT (1990): Syntactic variation in Greek of the $5^{\text {th }}$ century AD, Göteborg

JOSEPH (1983): The synchrony and diachrony of the Balkan infinitive, Cambridge

JANNARIS (1968²): An historical Greek Grammar, Hildesheim

KuRZOVÁ (1966): Zum Aussterben des Infinitivs im Griechischen, in: Les études balkaniques tchécoslovaques

I, 39-50

KURZOVÁ (1968): Zur syntaktischen Struktur des Griechischen 'Infinitiv und Nebensatz', Amsterdam

KÜHNER-GERTH (1904): Ausführliche Grammatik der griechischen Sprache I-II, Hannover und Leipzig

LJUNGVIK (1926): Studien zur Sprache der apokryphen Apostelgeschichten, Uppsala

LSJ: A Greek-English Lexicon, compiled by Henry George Liddel and Robert Scott, Oxford 199611

MAYERTHALER I: Willi Mayerthaler/Günther Fliedl/Christian Winkler: Infinitivprominenz in europäischen Sprachen, Teil I: Die Romania (samt Baskisch), Tübingen 1993

Mayerthaler II: Willi Mayerthaler/Günther Fliedl/Christian Winkler: Infinitivprominenz in europäischen

Sprachen, Teil II: Der Alpen-Adria Raum als Schnittstelle von Germanisch, Romanisch und

Slawisch, Tübingen 1995

MAYSER (1929): Grammatik der griechischen Papyri aus der Ptolemäerzeit I-II, Berlin und Leipzig

MinEvC-GABRovec (1960): Études sur la syntaxe de Ioannes Moschos, Ljubljana

ORESNIK (2001): A predictable aspect of (morpho)syntactic variants, Ljubljana

OREŠNIK (2004): Naturalness in (morpho)syntax: English examples, Ljubljana

OREŠNIK (1999): Krepke in šibke dvojnice v skladnji, Ljubljana

RADERMACHER (1911): Neutestamentliche Grammatik, Tübingen

RIJKSBARON (1984): The syntax and semantics of the verb in Classical Greek, Amsterdam

ROSENQUIST (1981): Studien zur Syntax und Bemerkungen zur Text der Vita Theodori Syceotae, Uppsala

RoHLFs (1962): Neue Beiträge zur Kenntnis der unteritalischen Gräzität, München

RoHLFS (1977): Grammatica storica dei dialetti italogreci (Calabria, Salento), München

SCHWYZER $\left(1959^{2}\right)$ : Griechische Grammatik II, München

Text editions

Vita Theodori Syceotae: Vie de Théodore de Sycéôn, I Text grec, II Traduction, commentaire et appendice, ed. Festugière, Bruxelles 1970

Pratum Spirituale: PG 87, 2852-3112, ed. Migne, Paris 1860

Povzetek

\section{GRS̆KI NEDOLOČNIK V VSEBINSKIH DELIBERATIVNIH, ZLASTI \\ ODVISNIH, VPRAŠALNIH STAVKIH: RAZLAGA S STALIŠČA TEORIJE NARAVNOSTI}

V prvem delu članka so predstavljene osnovne značilnosti rabe nedoločnika v vsebinskih odvisnih deliberativnih vprašalnih stavkih, kot so se razvile $\mathrm{v}$ poklasični in zgodnjebizantinski grščini. Poseben poudarek je namenjen nedoločniku v tej skladenjski vlogi v dveh zgodnjebizantinskih proznih delih (v Viti Teodorja iz Sikeona in v Pratum Spirituale), kjer so bile opažene nekatere novosti $\mathrm{v}$ primerjavi $z$ rabo nedoločnika v odvisnih vprašalnih stavkih v zgodnejših obdobjih. Drugi del prispevka predstavlja poskus interpretacije odvisnih deliberativnih nedoločniških polstavkov s stališča teorije naravnosti. 